\title{
Development of Learning Media Prezi Integrated Problem Based Learning Model (PBL) to Improve Student Results High School
}

\author{
Noviza Rizkia \\ Postgraduate Program of Chemistry Education \\ State University of Medan \\ Medan, Indonesia \\ novizarizkia92@gmail.com \\ Nurfajriani \\ Postgraduate Program of Chemistry Education \\ State University of Medan \\ Medan, Indonesia \\ Murniaty Simorangkir \\ Postgraduate Program of Chemistry Education \\ State University of Medan \\ Medan, Indonesia
}

\begin{abstract}
This study aims to determine: 1) the utilization of computer-based powerpoint learning media used in SMAN 1 Darul Falah has been in accordance with BSNP standards; 2) the utilization of integrated prezi learning media PBL model developed on salt hydrolysis discussion has been in accordance with BSNP standard; 3) differences in use of computer-based powerpoint learning media and prezi integrated learning media PBL model developed to improve student learning outcomes. The population in this study is all students of class XI IPA at SMAN 1 Darul Falah Academic Year 2017/2018. The sampling technique is purposive sampling. The sample of this research is two classes in SMAN 1 Darul Falah each 2 class. Research instrument in the form BSNP, objective test of valid learning result and reliable. Analytical technique used Two Way Anova technique and General Linear Model (GLM) test on SPSS 17.00 program. Analytical technique used Two Way Anova technique and General Linear Model (GLM) test on SPSS 17.00 program. The results concluded that: 1) The feasibility level of learning media based powerpoint computer used in SMAN 1 Darul Falah has a decent category; 2) The prezi integrated learning media PBL model developed has a very decent category; 3 ) there are significant differences in learning outcomes using computer-based powerpoint learning media and prezi integrated learning media PBL model developed.
\end{abstract}

Keywords- Prezi Learning Media, Problem Based Learning Model (PBL), Increased Learning Outcomes, Salt Hydrolysis.

\section{INTRODUCTION}

Learning is essentially the activity of teachers in membelajarkan students, which means making students in learning conditions. The process of learning done in the classroom is an activity to transform knowledge, attitude and skills. According Hamalik (2009) improving the quality of education can not be separated from the quality of the learning process because through the learning process will be obtained learning outcomes as expected in the learning objectives that have been formulated. The development of education in Indonesia today demands an improvement in the quality of good outcomes in science and technology. The way that can be done to improve the quality of the output is to make various improvements in the learning process. One of them is by finding the right model, method, or media to carry out teaching and learning process, all learning component is played optimally to reach the learning goal.

Learning activities between teachers and students as well as students with a student is a communication process that can be done, the communication will be more effective if it involves audio visual media, but the communication process itself just happened after the feedback. Better media is interactive, based on the description above it can be briefly stated that the learning media is a vehicle for channeling messages or learning information (Nurseto, 2011). According Hamalik (2009) utilization of media in learning can generate new desires and interests, increase motivation and stimulation of learning and even psychologically affect students.

Based on the results of interviews with one of the chemistry teachers at SMAN 1 Darul Falah school it is known that, Media presentations used by teachers in the classroom still use the media powerpoint with a very simple look. Powerpoint is considered as one of the alternative media that is easy to use and does not take time. Teachers still use conventional methods when explaining the subject matter. The results of interviews conducted by researchers to some students 
of class XI MIA in SMAN 1 Darul Falah expressed difficulty and less interest in chemistry subjects. The results of observations conducted by researchers showed that the facilities in the classroom is very supportive of teachers in improving their creativity in delivering the material. There are LCD projectors in the classroom, but there are still many teachers who do not utilize the existing facilities.

Taking into account the various problems that exist, it takes the media to attract attention and increase student activity so that generate interest in student learning, especially on the subject of salt hydrolysis. Learning media can also involve students actively in the learning process, so that students' understanding of the taught material will be more increased. Increased understanding of students on the material taught will improve student achievement.

There have been several previous studies on the development of prezi learning media, including research

\section{METHOD}

This research was conducted at SMAN 1 Darul Falah, Aceh province in November 2017 - April 2018. The population in this research is all students of class XI in SMAN 1 Darul Falah. Sample selection in research using purposive sampling technique. In the study selected two classes of IPA 2 and IPA 3.. The number of existing students is taken by 24 students for classes taught with prezi integrated learning media PBL model (Experiments) and 24 students for classes taught with powerpoint media (Control).

This research is generally a research that aims to develop a learning media, then the method used is method R \& D (Research and Development) by using Analysis-DesignDevelopment-Implementation-Evaluation (ADDIE) model. The research instruments used in this study were non-test and test. The non-test instrument consists of a BSNP questionnaire and the test sheet used is a multiple choice test on salt hydrolysis material.

The media feasibility validation sheet is used to measure the feasibility level of the developed medium. The form of the feasibility test sheet used in this study is a modified questionnaire from the BSNP standard. Questionnaires were given to 2 (two) chemistry lecturers of Medan State University and 2 (two) chemistry teachers as expert validators. The learning result test instrument is used to measure the effectiveness of learning media prezi integrated PBL model in terms of increasing students' knowledge. The test form in this study consisted of multiple objective problems of 35 questions with 5 options ( $a, b, c, d$ and e). The test sheet of students learning outcomes is based on the indicators contained in the salt hydrolysis material. This objective test is given at the time of pretest and posttest. To know the validity, reliability, level of difficulty of problems, and distinguishing power is done instrument test.

The observed data collected from material experts and media experts were analyzed descriptively using a linkert scale conducted by Zulhijjah, Noer, and Linda (2015) entitled "The Application Of Prezi Dekstop As Presentation Media To Improve Student Achievement On The Topic of Hydrocarbon In class X SMAN 9 Pekanbaru "the results of research based on the results of the test data analysis obtained t count $>$ ttable is 5.84> 1.66, meaning the application of Prezi Dekstop as a media presentation can improve student achievement on the subject Hydrocarbons in class X SMA Negeri 9 Pekanbaru.

Based on the description that has been proposed, the authors are interested in doing research on the development of learning media prezi on chemistry subjects with the title: "Development of Learning Media Prezi Integrated Problem Based Learning Model (PBL) to Improve Student Results High School".

with a score range of 1 to 4 , of which 1 was the lowest score and 4 as the highest score. Media feasibility data processing using the formula:

$$
\text { Media Feasibility Value }=\frac{\sum \text { scores obtained }}{\sum \text { items test }}
$$

(Widoyoko, 2012)

The increase that occurs before and after learning is calculated by the $\mathrm{g}$ factor formula (N-gain) with the Hake formula:

$$
\mathrm{N}_{\text {gain }}=\frac{\mathrm{S}_{\text {post }}-\mathrm{S}_{\text {pre }}}{\mathrm{S}_{\text {maks }}-\mathrm{S}_{\text {pre }}}
$$

(Meltzer, 2002)

Normality test using Kolmogorov-Smirnov test in SPSS 17.0 Data is said to be normal distribution if significant level> 0,05 . The homogeneity test was performed by using Levene test in SPSS 17.0 for windows program. After the prerequisite data analysis is met both normality and homogeneity of data, then can be continued testing hypothesis. The hypothesis was analyzed by using two way analysis of variance (Twoway ANAVA) using SPSS 17.0 for windows program. The data analyzed is $\mathrm{N}$-gain student learning outcomes (Sugiyono, 2010).

\section{RESULTS AND DISCUSSION}

Prior to conducting the research, firstly the researchers conducted an analysis of learning media powerpoint. Powerpoint learning media analysis was conducted by 3 chemistry teachers based on a media assessment questionnaire that has been validated by expert validators. The analysis was conducted to find out the feasibility level of learning media of powerpoint both from content feasibility, language feasibility and feasibility of presentation used in powerpoint Powerpoint analysis media analysis results are shown in Figure 1. 


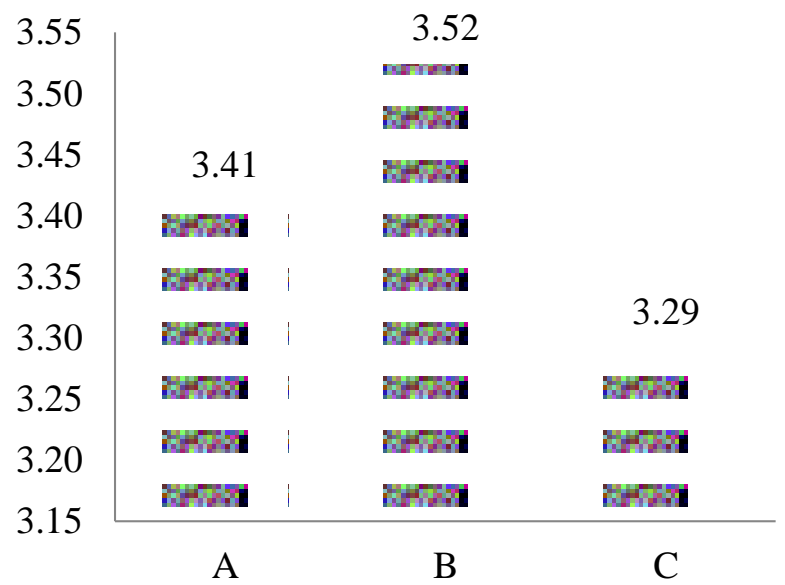

Fig 1 Graph of powerpoint analysis media analysis results

The result of powerpoint learning media analysis based on feasibility questionnaire of learning media include feasibility of content, language feasibility and presentation feasibility indicate that average value 3,41 means very feasible to be used.

Powerpoint analysis media analysis results on the content feasibility aspect has an average value of 3.3 , meaning it is worthy to use. There are 5 indicators related to content feasibility aspects, namely: I) material coverage $=3.5$ means very feasible; II) accuracy $=3.67$ means very feasible; III) term $=3.5$ means very worthy; IV) foster student's productive character $=3,33$ means very feasible; and V) stimulates curiosity $=2.5$ meaning worthy.

Powerpoint analysis media analysis results on the language feasibility aspect has an average value of 3.53 , meaning it is feasible to use. There are 7 indicators related to the language feasibility aspects, namely: I) in accordance with the development of students $=3.83$ means very feasible; II) communicative $=3.33$ means very worthy; III) Dialogic and interactive $=3.50$ means very worthy; IV) straightforward $=$ 3.67 means very feasible; V) procedure coherence and demands of thought flow $=3.67$ means very feasible; VI) Conformity with the correct Indonesian Rule $=3.17$ means feasible; and VII) The use of the terms, symbols and symbols = 3.56 means very feasible.
Powerpoint analysis media analysis results on the aspect of presentation feasibility has an average value of 3.19, meaning it is feasible to use. There are 3 indicators related to feasibility aspects of presentation that is: I) design / media display $=3.59$ means very feasible; II) visual and audio display $=2.80$ means feasible; and III) media operation $=3.17$ means feasible . Based on the above exposure, powerpoint learning media still needs to be revised. Things that need to be improved is to add additional audio-visual form into the media that will be developed.

Product development consists of product planning that contains the formulation of material items done by looking at the syllabus. The researcher also collected some relevant sources to support the material to be developed in prezi learning media. Next is the stage of product creation, the application to create a presentation media is a desktop prezi application. In making learning media prezi researchers divide several views, among others: initial display, integrated display material PBL model, learning video display, and display examples of practice questions.

Here's an initial look at prezi media for salt hydrolysis material at Figure 2. 


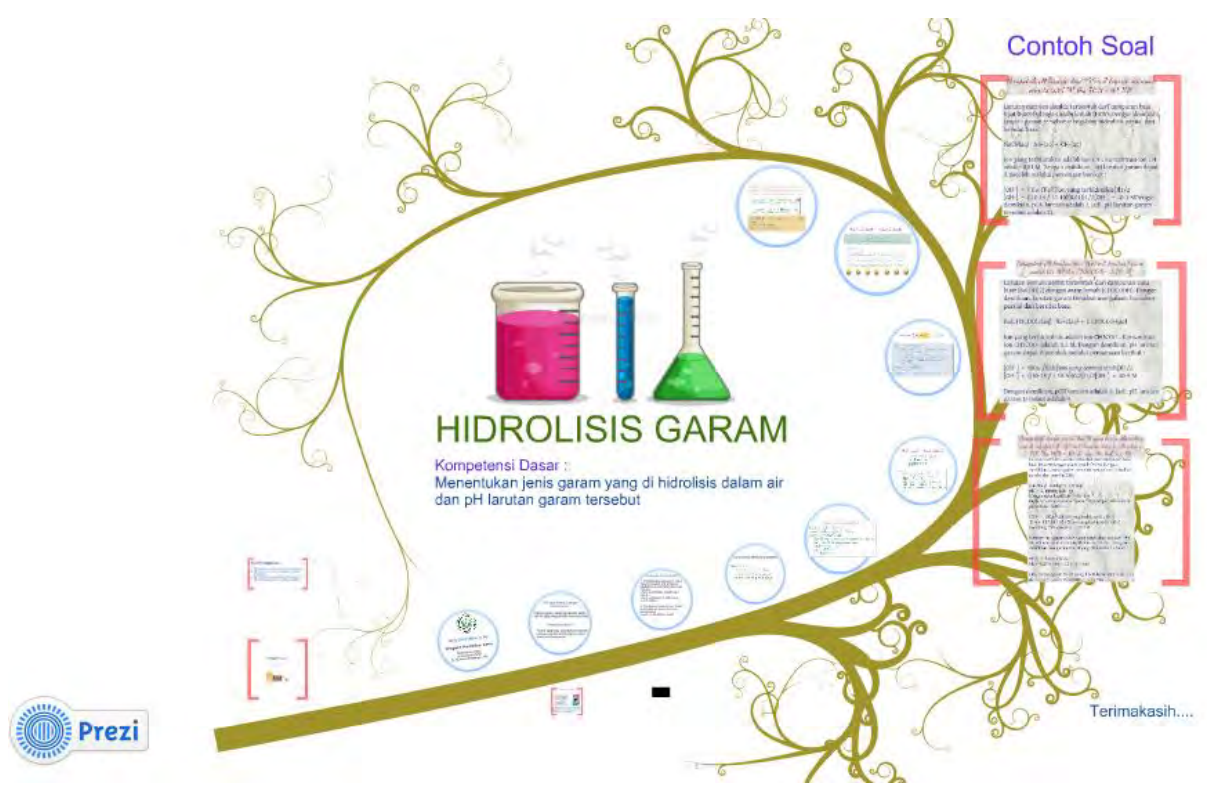

Fig 2. Cover of learning media prezi integrated PBL model

In the initial view in prezi learning media, users can see the whole teaching materials to be delivered. At the beginning of the display you will see the title of the material along with the entire display of the material, then if the user wishes to proceed to the basic competence display and teaching materials, the user must press the "next" button in the display screen.

The feasibility level of instructional media developed based on feasibility questionnaire of learning media include content feasibility, language feasibility and presentation feasibility can be seen in Figure 3

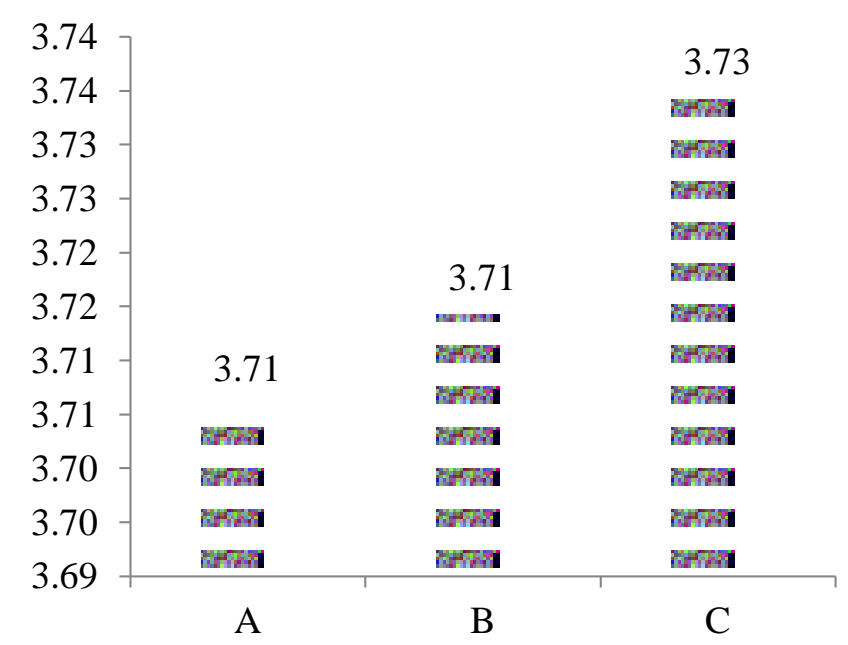

Fig 3 Graph of analysis result of feasibility of prezi learning media

The result of analysis of prezi learning media developed based on feasibility questionnaire of learning media covering the feasibility of content, language feasibility and presentation feasibility indicate that average value 3,72 means learning media developed very feasible to be used. while the 
powerpoint learning media has an average value of 3.41 means that learning media powerpoint is feasible enough to be used.

The result of analysis of prezi learning media that has been developed on the content feasibility aspect has an average value of 3.67 , meaning that it is feasible to use. There are 5 indicators related to the content feasibility aspects, namely: I) material coverage $=3.7$ means very feasible; II) accuracy $=3.8$ means very feasible; III) termination $=3.62$ means very worthy; IV) foster student's productive character $=3.5$ means very worthy; and V) stimulates curiosity $=3.75$ means very feasible.

The result of analysis of prezi learning media that has been developed on the language feasibility aspect has an average value of 3.71 , meaning it is very feasible to use. There are 7 indicators related to the language feasibility aspects, namely: I) in accordance with the development of students $=3.75$ means very feasible; II) communicative $=3.87$ means very worthy; III) Dialogic and interactive $=3.75$ means very worthy; IV) straightforward $=3.5$ means very worthy; V) procedure coherence and demands of thought flow $=3.62$ means very worthy; VI) Conformity with the correct Indonesian Rule = 3.75 means very worthy; and VII) The use of terms, symbols and symbols $=3.75$ means very feasible. are: I) design / media display $=3.8$ means very feasible; II) visual and audio display $=3.75$ means very feasible; and III) media operation $=3.37$ means feasible.

After validation (assessment) of prezi learning media developed, then prezi learning media developed is tested to students of class XI IPA. The test was conducted to find out the improvement of student learning outcomes after using prezi learning media developed and see how big the effectiveness of the use of prezi learning media developed in improving student learning outcomes.

The problem used as an instrument is a matter of multiple choice with 5 choices (a, b, c, d, and e) that have been validated by expert validators. The test was conducted by involving two classes consisting of experimental class and control class. Where the experimental class is taught using prezi learning media developed while the control class is taught using learning powerpoint media contained in the school. Description of research data in the form of learning outcomes obtained from pretest, posttest, and student learning achievement data which can be seen in appendix 11 for both classes are summarized in the graph below.

The result of analysis of prezi learning media that has been developed on the aspect of presentation feasibility has an average value of 3.64 , meaning that it is feasible to use. There are 3 indicators related to the feasibility aspects of presentation

TABLE 1. Descriptive Statistics Pretest Sample Group

\begin{tabular}{cccc}
\hline No & Descriptive & Experiment & Control \\
\hline 1 & Mean & 28 & 28 \\
2 & Standard Deviation (SD) & 7,26 & 5,79 \\
3 & Maximum & 44 & 40 \\
4 & Minimum & 16 & 12 \\
\hline
\end{tabular}

In the learning of salt hydrolysis material for experimental class (preg integrated learning medium PBL model) obtained pretest result obtained highest score 44 and lowest score 16, with mean $(\mathrm{M})=28$ and standard deviation $(\mathrm{SD})=7,26$ and for class control (powerpoint learning media) obtained pretest results obtained the highest score of 40 and the lowest score 12 , with average $(M)=28$ and standard deviation $(S D)=5,79$. This indicates that the pretest grade of the experimental class is higher than control class

TABLE 2. Descriptive Statistics Posttest Sample Group

\begin{tabular}{cccc}
\hline No & Descriptive & Experiment & Control \\
\hline 1 & Mean & 81 & 76 \\
2 & Standard Deviation (SD) & 5,21 & 4,91 \\
3 & Maximum & 88 & 84 \\
4 & Minimum & 72 & 64 \\
\hline
\end{tabular}

In the learning of salt hydrolysis material for the experimental class (preg integrated learning medium PBL model) obtained the result of the highest score of 88 and the lowest score 72, with mean $(\mathrm{M})=81$ and standard deviation $(\mathrm{SD})=5.21$ and for class control (powerpoint learning 
media) obtained the postest score obtained the highest score of 84 and the lowest score 64, with average $(\mathrm{M})=76$ and standard deviation $(\mathrm{SD})=4.91$. This indicates that the postest grade of the experimental class is higher than that of the control class.

TABLE 3. Descriptive Statistics Gain Sample Group

\begin{tabular}{cccc}
\hline & Descriptive & Experiment & Control \\
No & & & \\
\hline 1 & Mean & 0,74 & 0,66 \\
2 & Standard Deviation (SD) & 0,08 & 0,07 \\
3 & Maximum & 0,85 & 0,78 \\
4 & Minimum & 0,56 & 0,53 \\
\hline
\end{tabular}

In the learning of salt hydrolysis material for the experimental class (pregroup learning media integrated PBL model) obtained the result of gain obtained the highest score 0.85 and the lowest score 0.56 , with average $(\mathrm{M})=0.74$ and standard deviation $(\mathrm{SD})=0.08$ and for the control class (powerpoint learning media) the highest score was 0.78 and the lowest score was 0.53 , with mean $(\mathrm{M})=0.66$ and standard deviation $(\mathrm{SD})=40.07$.

The result of hypothesis testing using two path ANAVA for first hypothesis obtained probability value or sig. $0.001<0.05$ so that the first hypothesis received $\mathrm{Ha}$ and it was concluded that there is a significant effect on the improvement of student learning outcomes. Zulhijjah, Noer, and Linda (2015) stated that the application of prezi dekstop as presentation media can improve student achievement on Hydrocarbon subject in SMA Negeri 9 Pekanbaru. Increased category of experimental learning achievement including high class with normalized $\mathrm{N}$ gain of 0.74. Meanwhile, the category of improvement of learning achievement of control class including moderate with normalized $\mathrm{N}$-gain of 0,54 .

\section{CONCLUSION}

1) The feasibility level of learning media based powerpoint computer used in SMAN 1 Darul Falah has a decent category.

2) The prezi integrated learning media PBL model developed has a very decent category.

3) There are significant differences in learning outcomes using computer-based powerpoint learning media and prezi integrated learning media PBL model developed.

\section{REFERENCES}

[1] Aduwa-Ogiegbaen, S. E., \&Iyamu, E. O. S. (2005). Using information and communication technology in secondary schools in Nigeria: Problems and prospects. Educational Technology \& Society, 8(1), $104-$ 112 .

[2] Akgun, O., \& Erkan .(2016). Effects of lectures with powerpoint or Prezi presentations on cognitive load, recall, and conceptual learning. International Online Journal of Educational Sciences, 8(3), 1-11.

[3] Arsyad, A. (2011). Media Pembelajaran. Jakarta: PT. Raja Grafindo Persada.

[4] Dzulhijjah, P. D., Noer, A. M. N., \& Linda, R. L. (2015). Penerapan Prezi Dekstop Sebagai Media Presentasi Untuk Meningkatkan Prestas Belajar Siswa Pada Pokok Bahasan Hidrokarbon Di Kelas X Sma Negeri 9 Pekanbaru. Jurnal Online Mahasiswa (JOM) Bidang Keguruan dan Ilmu Pendidikan, 2(2), 1-11.
[5] Hamalik, O. (2009). Strategi Belajar Mengajar. Bandung: Pustaka Martiana.

[6] Nurseto, T. (2011). Membuat Media PembelajaranYang Menarik, Fakultas Ekonomi Universitas Negeri Yogyakarta, Jurnal Ekonomi \& Pendidikan, 8(1).

[7] Sugiyono. (2010). Metode Penelitian Kuantitatif Kualitatif dan R\&D. Bandung: CV Alfabeta.

[8] Widoyoko, E. (2012). Teknik Penyusunan Instrumen Penelitian.Yogyakarta: Pustaka Pelajar. 